\title{
COMMUNITY PARTICIPATION IN TOURISM PLANNING AT MAJETE WILDLIFE RESERVE, MALAWI
}

\author{
FELIX G. BELLO (1) \\ Department of Marketing Management, University of Pretoria, Pretoria, South Africa
}

Manuscript received: April 21, 2021

Revised version: August 25, 2021

Bello F.G., 2021. Community participation in tourism planning at Majete Wildlife Reserve, Malawi. Quaestiones Geographicae 40(4), Bogucki Wydawnictwo Naukowe, Poznań, pp. 85-100. 2 figs, 2 tables.

\begin{abstract}
This research assessed the local community's participation in protected area-based tourism planning at Majete Wildlife Reserve in Malawi. The assessment was based on the participatory planning elements from the community participation framework for protected area-based tourism planning. A qualitative research approach was applied, and both secondary and primary data sources were used. Content analysis was used to analyse the data. Results show that the reserve has a system that allows continuous local community participation in the planning process, with financial resources committed to support the process. Local people are represented by independent community-based organisations and traditional leaders during the planning processes. But the local communities have limited access to tourism information and tourism planning experts. The reserve also lacks an appropriate decision-making structure that can facilitate efficient flow of management decisions to local communities. There is need to empower local people and regard them as partners in the tourism planning processes so that they can influence decisions.
\end{abstract}

KEYWORDS: community participation framework, Malawi, protected area-based tourism, tourism planning

Corresponding author: Felix G. Bello, Department of Marketing Management, University of Pretoria, Private Bag X20, Hatfield, Pretoria, 0028 South Africa; e-mail: felix.bello@up.ac.za; felixbello2015@gmail.com

\section{Introduction}

The need to promote 'the common good of society' has led to advocacy of different forms of planning over the years. With tourism being an important economic development sector, planning is mainly initiated to ensure that economic benefits and visitor satisfaction are enhanced and community integration and resource protection are improved (Rasoolimanesh et al. 2017; Giampiccoli, Glassom 2021). In some cases, tourism planning is initiated as a response to negative impacts of tourism development and to make destinations more attractive and competitive (Hall 2008). Contributing to the economy is one of the priority goals for tourism development in many developing countries. Therefore, when planning for tourism development, factors that influence tourism's success should always be considered (Gunn, Var 2002; Lalicic, Onder 2018). These factors include the following: geographical relationship to markets, attractions and attractiveness, resources for development and stakeholder involvement (Gunn, Var 2002). As tourism mostly depends on cultural and natural resources, tourism planning further emphasises the protection of these resources.

Stone and Nyaupane (2018) have noted that any planning associated with protected areas involves addressing overlapping goals of

\section{sciendo}


biodiversity conservation and local community development. Protected area-based tourism is believed to be the tool which provides linkages between biodiversity and community development. For sub-Saharan Africa, community-based tourism is promoted around protected areas as a win-win strategy for local development and biodiversity conservation (Sène-Harper, Séye 2019). But Okazaki (2008) and Lekaota (2016) argue that the community-based tourism model works effectively on the basis of local community participation and empowerment. Although there is high consensus on the involvement of local communities in the tourism planning and development process, Ashley et al. (2015) have noted that there is little information on how local communities can be engaged in decision-making. Therefore, this research aims to assess local community participation in protected area-based tourism planning at Majete Wildlife Reserve in Malawi.

\section{Tourism planning}

There have been considerable changes in tourism planning over the past decades. Tosun and Jenkins (1998) break the evolution of tourism development planning into five stages: the unplanned tourism development era, beginning of partly supply-oriented tourism planning period, entirely supply-oriented tourism planning period, market- or demand-oriented tourism development planning period and the contemporary planning approach period. These stages are continuous and have evolved over time, and as such they are not distinctive and separate. During the period of unplanned tourism development, tourism planning was uncommon and many destinations did not understand the impacts of tourism development. After this period, the main concern was for tourism infrastructure development where tourism planning was primarily about building hotels, restaurants and transport facilities (Tosun, Jenkins 1998). This led to haphazard development of tourism facilities as the major concerns were satisfying the rapidly increasing tourism demand and maximising profit. During the market- or demand-oriented tourism planning period, the focus of planning was on attracting as many tourists as possible to ensure that tourist facilities operated at optimal levels. The supply- and demand-oriented tourism planning stages resulted in a number of social and environmental consequences.

The negative impacts of tourism led to the need to consider environmental, social and cultural issues alongside economic factors during the tourism planning process (Tosun, Jenkins 1998; Nunkoo, Gursoy 2016). As a result, several contemporary approaches have been adopted when planning for the development of tourism. These approaches include the following: the economic, industry-oriented approach, the physical/spatial approach, the system approach, the integrated planning approach, the comprehensive planning approach, the continuous and flexible approach, the strategic planning approach, the sustainable tourism development approach and the community participation approach (Tosun, Jenkins 1998; Baidal 2004; Hall 2008).

The sustainable development approach to tourism planning emphasises the need to conserve natural, cultural and other resources because maximum tourism development depends on these resources (Stone, Nyaupane 2018). In other words, the approach seeks the development of tourism that meets the primary objective of sustainable development, which is to provide lasting and secure livelihoods with "minimal resource depletion, environmental degradation, cultural disruption and social instability" (Hall 2008: 62). It is argued that sustainable tourism development greatly helps the justification and meeting of conservation costs for a destination (Stone, Nyaupane 2018). In order to avoid environmental degradation, the approach emphasises the need to carefully survey and analyse environmental elements in the determination of the appropriate type and location of tourism development (Inskeep 1994; Mowforth, Munt 2009). The approach is also aimed at equitable distribution of benefits and costs of tourism development and the need to involve local communities in the planning and development process (Dragouni, Fouseki 2018).

The community participation approach in tourism planning traces its origin to studies done in the late 1970s that criticised the negative sociocultural impacts of tourism development (de Kadt 1979). This approach highlights the need for wider involvement of local communities in tourism and emphasises the need to involve local 
residents in tourism planning and development decisions in order to minimise the negative impacts and maximise the positive impacts of tourism development in a community (Sène-Harper, Séye 2019; Lalicic, Weber-Sabil 2020; Zhang et al. 2020). As noted by Nowack et al. (2018), tourism development in any region should improve the quality of life of the local community. The approach has mainly been revitalised by the need to achieve social involvement in the planning process, as advocated in Murphy's (1985) work, which provides the basic reference point.

Bramwell et al. (2017) indicate that sustainable tourism research needs to go beyond analysing the behaviours of individual actors and rather consider wider social relations and structures and institutional roles. A protected area-as any tourism destination-has complex stakeholder groups with different interests (Pyke et al. 2018). Therefore, community participation in tourism planning should aim to change the balance of power among the stakeholders to benefit all stakeholders, including members of the local community (Bahaire, Elliot-White 1999; Dodds et al. 2018; Panichm et al. 2018). As such, tourism planners need to understand the allocation of power among the different stakeholders involved in tourism planning and development processes and accept the need to place local communities at the centre of tourism development (Nunkoo, Gursoy 2016; Moswete, Thapa 2018). Although community-based tourism planning process is highly desirable, there are a number of operational, structural and cultural limitations to the approach in developing countries (Tosun 1999). Some of the limitations to community-based tourism planning include apathy, inadequate financial resources, inadequate information, low education levels, unfair distribution of benefits, lack of trained human resource, centralised public administration, lack of coordination and human-wildlife conflicts (Tosun 2000; Marzuki et al. 2012; Saufi et al. 2014; Bello et al. 2017; Dodds et al. 2018).

Community participation in tourism takes different forms which include employment, enterprise ownership, collective or individual management of community enterprises, leasing or investment of resources through joint ventures and participation in decision-making during tourism planning (Ashley, Roe 1998; Strydom et al. 2018; Mandić 2020). The focus of most studies in the sub-Saharan African region has mainly been on the performance of community-based initiatives and the impacts or prospects of protected area-based tourism (Mahony, Van Zyl 2002; Mbaiwa 2003, 2005a, 2005b, 2005c; Novelli et al. 2006; Spenceley, Goodwin 2007; Stone, Stone 2011; Snyman 2012). Although the participation of local communities in decision-making during the tourism planning processes leads to higher legitimacy of tourism policies and plans (Dragouni, Fouseki 2018) and facilitates the development of more socially acceptable tourism with more benefits to local communities (Hall 2008), most of the studies do not focus on the planning aspects. Therefore, this paper assesses the nature of community participation in tourism planning associated with protected areas.

\section{Community participation framework for protected area-based tourism planning}

The community participation framework for protected area-based tourism planning by Bello et al. (2016) has seven major participatory planning elements, namely timing of involvement, resource accessibility, representativeness, independence, influence and power, transparency, and the decision-making structure. The participatory tourism planning approach in this framework aims to achieve local community empowerment, sustainable protected area tourism development and biodiversity conservation, as shown in Figure 1.

Bello et al. (2016) argue that the timing of involvement of local people is critical in any participatory development process. Local communities should be involved early enough during the planning process (Gray 1989; Bramwell, Sharman 1999; Nkemngu 2014). Furthermore, participants should have access to financial, informational, human and material resources to facilitate their effective participation in the planning process (Paul 1987; Pearce 1991; Rowe, Frewer 2000; Tosun 2000; Hall 2008). In the context of participatory tourism planning, Bello et al. (2016) indicate that local communities need to be represented by legitimate individuals who are identified by the local people. The other planning element in the framework is the independence of the local community representatives. As argued by Rowe and Frewer (2000: 13), the representatives 


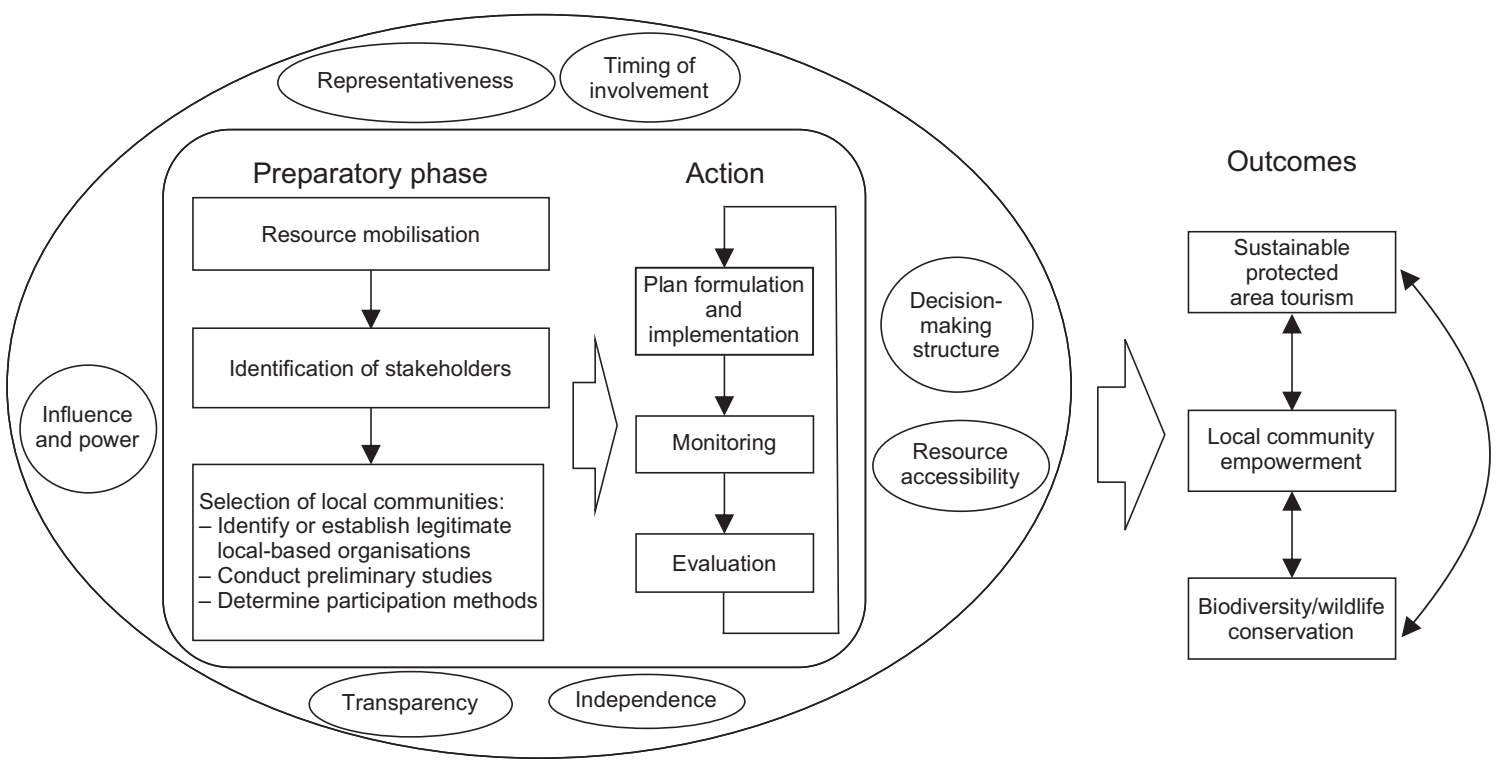

Fig. 1. Community participation framework for protected area-based tourism planning. Source: Bello et al. (2016).

"should be independent of any affiliation to the sponsoring body".

The framework further advances the need for local people to gain influence over aspects of the tourism planning process. This is achieved when the local communities are empowered and regarded as partners in the process. Power arrangements are critical in the analysis of the political dimensions of tourism issues at community level (Nunkoo, Gursoy 2016). The tourism planning process is also expected to be transparent enough to ensure that the local people that surround the protected areas see how the process is progressing and how decisions are being made. Such transparency would reduce any possible suspicions about the motives of the planning authorities or other stakeholders (Bello et al. 2016). Lastly, to facilitate effective local community participation in the planning processes, appropriate mechanisms in structuring the decision-making process should be applied (Rowe, Frewer 2000). As such, Bello et al. (2016) recommend that the planning authorities should be open regarding the underlying reasons behind the decisions made during the planning process.

\section{Research context - protected area tourism planning process in Malawi}

Any protected area needs a management plan that outlines how it should be protected, used, developed and managed (Eagles et al. 2002; Dudley, Stolton 2018). The protected area management plan addresses a number of issues pertaining to the desired state of the protected area. In Malawi, protected area-based tourism is mainly planned within the framework of the protected area general management plan. Comprehensive planning for protected areas in Malawi started in the early 1980s, with the preparation of the Principal Master Plan for National Parks and Wildlife Management in 1983 (Clarke 1983a). Other protected area master plans for the southern, central and northern regions, with sections for specific national parks and wildlife reserves, were also drawn up in 1983 (Clarke 1983b). These protected area master plans have formed the basis for specific protected area management plans that have been developed over time.

Table 1. Protected areas in Malawi (wildlife reserves and national parks).

\begin{tabular}{|l|r|}
\hline \multicolumn{1}{|c|}{ Name of protected area } & Size $\left(\mathrm{km}^{2}\right)$ \\
\hline Majete Wildlife Reserve & 704 \\
\hline Mwabvi Wildlife Reserve & 135 \\
\hline Nkhotakota Wildlife Reserve & 1,800 \\
\hline Vwaza Marsh Wildlife Reserve & 1,000 \\
\hline Kasungu National Park & 2,100 \\
\hline Lengwe National Park & 900 \\
\hline Nyika National Park & 3,200 \\
\hline Liwonde National Park & 548 \\
\hline Lake Malawi National Park & 94 \\
\hline
\end{tabular}

Source: Department of National Parks and Wildlife. 


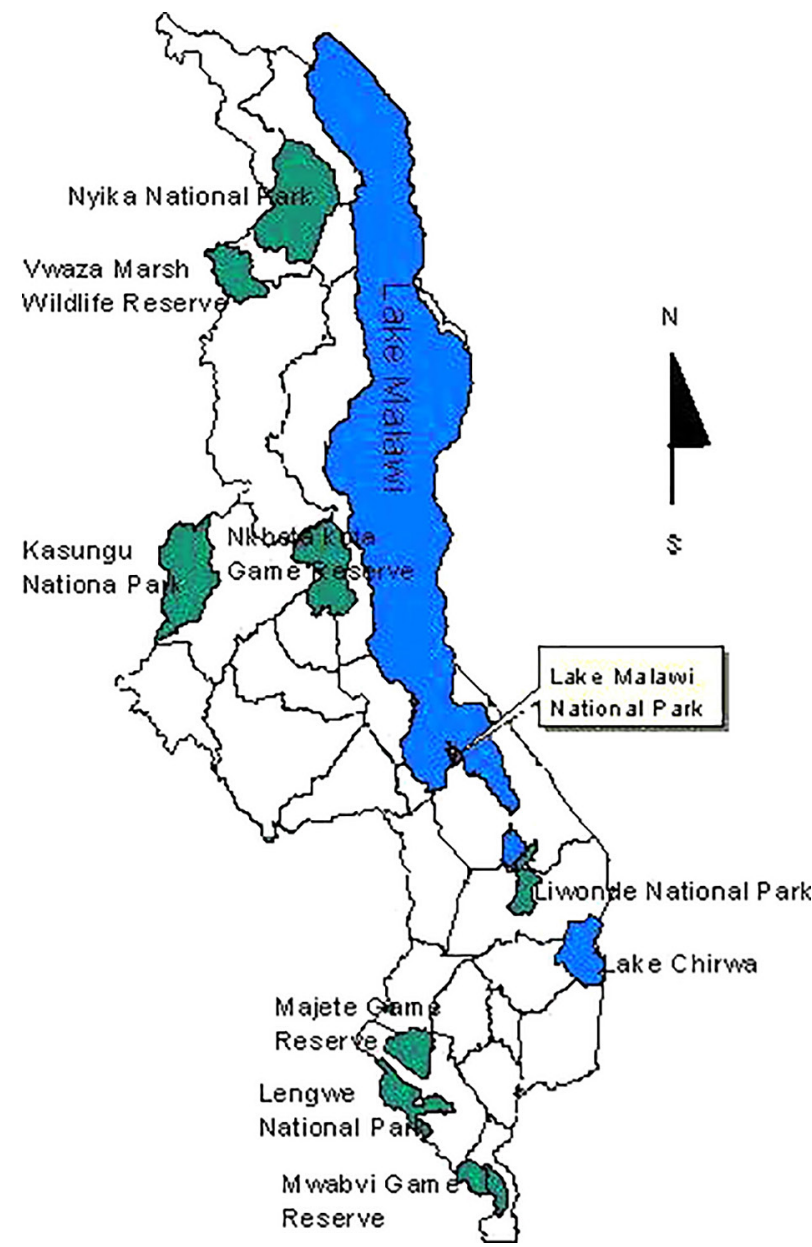

Fig. 2. Malawi's Protected Areas, according to the National Parks and Wildlife Act.

Source: Department of National Parks and Wildlife.

The other protected area tourism planning is done within the national tourism planning framework, and this is a more site-specific planning with tourism developments of national interest proposed at a particular site within a protected area (Malawi Government 2001, 2005; Department of Tourism 2006). Malawi has four wildlife reserves, namely Majete, Mwabvi, Nkhotakota and Vwaza Marsh, and five national parks, namely Kasungu, Lengwe, Nyika, Liwonde and Lake Malawi (Table 1 and Fig. 2).

\section{Majete Wildlife Reserve}

Majete Wildlife Reserve is located in the southern region of Malawi (Fig. 2). Part of the reserve, i.e., the area around Majete Hill, was first proclaimed a 'non-hunting controlled area' in 1951 (Hayes 1972). The reserve, covering an area of $520 \mathrm{~km}^{2}$, was proclaimed as a protected area in 1955 and was extended by $184 \mathrm{~km}^{2}$ in 1969 to include some dry-season water sources, such as the Shire River, for wildlife (Department of National Parks and Wildlife [DNPW] 2000). The reserve was then declared in its present state by the Proclamation of Alteration of Boundaries in 1976. The reserve now covers an area of $704 \mathrm{~km}^{2}$ (DNPW 2000). The major part of the reserve lies within the Chikwawa District (about 90\%), while the extreme northern section lies within the Mwanza District (DNPW 2000). The reserve also borders the Neno and Blantyre districts.

Majete Wildlife Reserve is under the management of the conservation organisation African Parks. The reserve is government-owned and was under the management of the DNPW until 2003, when African Parks was given a 25-year full management responsibility. The reserve is the first in Malawi to be managed under the Public-Private Partnership model. Though African Parks is a not-for-profit organisation, the management of Majete is based on a business model with a focus on making the reserve self-sufficient in its operations. In this regard, the General Management Plan for the reserve is a business plan that reflects the model of protected area management for African Parks.

With regard to literacy levels, for the population aged $\geq 15$ years, the literacy rate in Malawi was $75.5 \%$ in 2020 (National Statistical Office [NSO] 2020). In the case of the Chikwawa District, from where the local community participants for this study were selected, the literacy levels are below the national rate, at $66.9 \%$ (NSO 2020). The lower literacy levels in the case study district render the uptake of new initiatives, such as tourism development, among local communities difficult. The low understanding of the tourism industry and higher incidence of poverty lead to apathy among the local people in terms of involvement in most planning processes as most of the local people are preoccupied with activities related to their basic survival (Stone, Stone 2011).

The focus of this research is on the reserves' 2013-2017 business plan. This plan served as a working document for the management and development of the reserve during the five-year period. The five-year plan formed the basis for the reserves' annual business plans, which were formulated and rolled out each year to reflect various changes in the management of the reserve. 
These plans were produced by the management team of the reserve after involving various stakeholders to varied degrees. In acknowledging the need to make tourism the hub for economic activities, African Parks develops a separate tourism development strategy/plan for the reserve from the business plan for the reserve.

African Parks has developed a constituency for conservation and cultivated a working relationship with various stakeholders, including tour operators, non-governmental organisations (NGOs), local district assemblies, DNPW and local communities through community-based organisations (African Parks 2013b). The agency interfaces with local communities through community-based organisations (CBOs), the Majete Wildlife Reserve Association (MWRA) and traditional leaders. A CBO is a village-level committee responsible for coordinating natural resource management and developmental activities on behalf of the villages under a Group Village Headman. The MWRA is a grouping of chairpersons of the 19 CBOs that surround the reserve. Traditional authorities surrounding the reserve, representatives from interested NGOs and government departments from Chikwawa, Mwanza, Blantyre and Neno district councils are co-opted members of the MWRA (MWRA minutes 2007). There is also a Joint Liaison Committee (JLC), which is composed of key stakeholders representing relevant government institutions, traditional authorities, NGOs, CBO representatives and African Parks (JLC minutes 2005).

African Parks conducts monthly meetings with CBOs, quarterly meetings with the MWRA and the JLC and annual general stakeholders' meetings. At the $\mathrm{CBO}$ and MWRA levels, African Parks is mostly represented by junior officers, while very senior officers represent the agency at all the JLC meetings (MRWA minutes 2011-2012, JLC minutes 2011-2012). Various stakeholders are mainly asked to provide their input on tourism development and other management issues through these meetings. African Parks also carries out socioeconomic surveys in communities around the reserve in order to profile local people's livelihood. The information from such surveys assists African Parks in documenting the challenges being faced by the local communities, and the same data is used to support community development project proposals that are submitted to various donors by African Parks on behalf of the local communities.

\section{Methodology}

A qualitative approach was applied for this study. Qualitative research provides "a detailed account of what goes on in the setting being investigated" (Bryman, Bell 2007: 418). In-depth semi-structured interviews were used as they are non-directive and provide a better understanding of opinions, values, attitudes, feelings and the things that people have in common (Arskey, Knight 1999; Chisnall 2005). The 36 participants for this research were recruited through a purposive sampling approach. Purposive sampling was used to facilitate the selection of information-rich participants with respect to the aim of the study. The participants were drawn from among the local people surrounding the reserve, African Parks, DNPW, Department of Tourism, NGOs and tourism operators, as outlined in Table 2. Only senior officers from African Parks, DNPW, Department of Tourism, NGOs and managers of tourism operators were selected. The local community participants were sampled from three CBOs, and only those who had lived in the area for at least 10 years and had done primary school education, as well as CBO leaders, were selected. Accessibility and distance from tourist facilities were the major factors used in the selection of the three CBOs (namely Bwemba, Kandeu and Mthumba). The Bwemba CBO is along the tourist route and near the reserve's entrance, hence the closest to tourist facilities in the reserve. The Kandeu and Mthumba CBOs are easily accessible

Table 2. Profile of study participants.

\begin{tabular}{|l|r|c|c|}
\hline \multicolumn{1}{|c|}{ Stakeholder group } & Male & Female & $\begin{array}{c}\text { Number of } \\
\text { participants }\end{array}$ \\
\hline Local communities & 11 & 5 & 16 \\
\hline African Parks & 2 & 1 & 3 \\
\hline DNPW & 3 & 0 & 3 \\
\hline Department of Tourism & 4 & 0 & 4 \\
\hline Tourism operators & 5 & 1 & 6 \\
\hline NGOs & 4 & 0 & 4 \\
\hline Total & 29 & 7 & 36 \\
\hline
\end{tabular}

DNPW - Department of National Parks and Wildlife; NGO - non-governmental organisation.

Source: author's field data. 
communities, but on the blind side of any tourist activity associated with the reserve.

The total number of participants was guided by the attainment of theoretical saturation (Patton 2002). In this regard, data collection was stopped when no new categories or themes emerged from the interviews, signalling that data collection was complete. All the interviews were digitally recorded after getting consent from the interviewees, and the researcher did all the interviews face to face. A semi-structured interview guide was used for each stakeholder group, and some of the questions included the following:

- Is your local community involved in tourism planning associated with the protected area? How? Why or why not?

- What participation methods are used?

- What are the benefits of your community's participation?

- How does your community interact with other stakeholders involved in tourism planning?

- What is the role of your organisation in tourism planning?

- What are the barriers for local community participation in tourism planning?

The paper has also made use of data collected from secondary sources (both published and unpublished), which include policy documents on wildlife and tourism in Malawi, African Parks' annual reports and minutes of stakeholder meetings.

Content analysis was used to analyse the qualitative data from the interviews and documents. The six steps of data analysis and interpretation, as proposed by Creswell (2009), were followed in this study to analyse the data, and these steps are as follows: organising and preparing data for analysis, reading through all the data, coding, description, representation and interpretation. All the interviews were transcribed verbatim to ensure that a detailed record of all the interviews was captured. The data was then coded. The codes used were predetermined topics or themes that address a larger theoretical perspective in the research. During the coding process, similarities, consistencies and possible interpretations were also noted. The themes have been presented in narrative passages to convey the findings of the study.

\section{Results and discussion}

The discussion is organised based on the seven participatory planning elements from the community participation framework for protected area-based tourism planning, proposed by Bello et al. (2016).

\section{Representativeness}

The local communities around the reserve were represented in the planning processes by CBO leaders and traditional chiefs. In order to avoid traditional chiefs' domination of the local community representation in the planning processes, they were not allowed to be part of an executive committee for a CBO. As explained by a participant from an NGO-the Coordinating Unit for the Rehabilitation of the Environment (CURE):

... the use of community organisations has been tried in development projects and you will find that most of them included the chief. But whenever the chief is active in these communities, there are always problems which arise. Firstly, he is the owner of the land and so when it comes to things of sharing benefits, he will share with his peers, children and so on...so, to circumvent that, normally we involve them but not as an active member. So, you can have a chair from the rest of the village with up to 10 committee members and then you say, okay fine, and then our Village Headman or Group Village Headman becomes our advisor [Mwimba].

The CBO system has been endorsed by the local people and ensures that traditional chiefs do not interfere in the daily operations of the organisations that are established to represent local people in the planning processes. The community organisation eliminates the challenge of traditional chiefs' domination in tourism development activities faced by local communities in developing countries. In order to avoid antagonism between the traditional power structures and the CBO structures, representatives of traditional chiefs are members of the JLC at Majete. As noted by Novelli and Scarth (2007), and Chiutsi and Saarinen (2019), such community organisations are more inclusive and are expected to facilitate transparent and effective participation while removing the mistrust some local people 
have towards being represented only by traditional chiefs in the planning process.

In addition to having direct interaction with African Parks' education and extension officers in their respective villages, local communities are represented by $\mathrm{CBO}$ representatives at the MWRA and JLC meetings where tourism development issues are also discussed (MWRA minutes 2011-2012, JLC minutes 2007-2012). At the JLC meetings, the $\mathrm{CBO}$ representatives are also joined by traditional chiefs. There is a fair representation of the local communities, and this ensures that local people are accorded with the opportunity to contribute to the planning process and defend their interests. The tourism planning process needs to be representative of all affected interests (Dolds et al. 2018; Panichm et al. 2018; Strydom et al. 2018). As indicated by $96 \%$ of the respondents $(\mathrm{n}=36)$ from the local communities, DNPW, African Parks and NGOs, the local people are happy with their representation in the planning processes. Only a few respondents were not content as they felt that some representatives were not committed to their roles as they were frequently absent from meetings.

\section{Timing of involvement}

It emerged from the study that the initial stages of the tourism planning process are initiated and designed by the management agency (African Parks 2013b). Furthermore, there is continuous engagement of local communities throughout the year discussing the progress being made by African Parks, and such engagement informs the annual business plan for the reserve. It was explained by one of the $\mathrm{CBO}$ leaders.

... as a $\mathrm{CBO}$ we carry out several activities including community meetings in our villages. We conduct such activities on our own and together with African Parks staff. We report issues from our CBO at Association meetings and issues which are not resolved are then taken to Joint Liaison Committee meetings. We do this throughout the year. Some of the issues being implemented come from these discussions which are on-going throughout the year [Malizani].

In any development planning process, local people should be involved as early as possible or as soon as practical in the process (Gray 1989;
Bramwell, Sharman 1999; Rowe, Frewer 2000). The reserve has a planning system that allows continuous local community participation, thereby allowing timely involvement of local people in the processes that lead to the development of annual business plans for the reserve. It is necessary to subject any underlying assumptions and the agenda setting for tourism development in protected areas to public debate. Local communities need to have a fair understanding of the structure of the tourism industry, as well as its benefits and costs, before they can meaningfully participate in the planning process (Simmons 1994; Lekaota 2016; Chiutsi, Saarinen 2019). It is therefore vital for all key stakeholders in any planning process to be involved early enough since "failure to include them in the design stage only invites technical or political difficulties during implementation" (Gray 1989: 65).

\section{Independence}

The establishment of the CBOs was facilitated by the management agency. Though this is the case, the selection of representatives from these community structures is solely the responsibility of the local people. Furthermore, African Parks has no control over the appointment of traditional chiefs who are chosen per chieftaincy customs for a particular tribe. These traditional chiefs are-at some point-invited to participate in the planning processes. As explained by one CBO leader:

\footnotetext{
...we manage our $C B O$ s on our own though we get some support from African Parks. Executive Committee members are elected by the people themselves. People choose those they feel will represent them well. At the association and the Joint Liaison Committee, it is the same; leaders are elected by local people [Malizani].
}

Haywood (1988), and Novelli and Scarth (2007) argue that local communities should be allowed to select their own representatives to participate in the tourism planning process. $\mathrm{CBO}$ leaders representing local communities in the tourism planning processes are elected by local people from the surrounding villages. During JLC meetings, local senior chiefs or Traditional Authorities (TAs) are also invited to take part. The identification of local community representatives 
to be involved in the tourism planning process is independent of any affiliation to the protected area management agency. But it was noted that African Parks still takes a leading role in coordinating the activities of the organisations and - at times - in providing financial support or assisting in the identification of potential sponsors for community projects (African Parks 2013a, 2013b). It was acknowledged by all participants from the management agency that the community organisations carry out most of their activities independently (mainly conservation-related activities) and only report to the agency on what they have been doing in their respective communities.

\section{Influence and power}

The study has revealed that local communities have very low understanding of tourism-related issues. As a result, their contributions during the planning processes are skewed towards the needs of the management agency. It was explained by a participant from the NGO Wildlife and Environment Society of Malawi (WESM).

The local people have very little understanding of tourism. In our programmes we have engaged the local communities surrounding Majete. These people would want to benefit from the parks but due to high poverty levels in these communities people accept to be engaged in any tourism-related income generating activity which has a sponsor. There are IGAs [Income Generating Activities] which are not doing well and we have come to an understanding that given a choice these people couldn't have started those IGAs. It looks like the local people have very limited choices if any at all [Msonda].

The protected area management agency initiates the planning process and is responsible for the plan's implementation (African Parks 2013b). As a result, during the planning processes, the local communities are influenced to opt for recommendations that the management agency puts forward and that they will be in a position to implement. As explained by one tour operator, the focus of local communities in tourism development is mainly on the sharing of benefits such that the local people are mostly enticed to opt for protected area- or tourism-related income-generating activities which other stakeholders have promised to support. Due to limited capacity, the local communities have mainly been recipients in the whole process, as indicated by one $\mathrm{CBO}$ leader:

...you know I have to be honest; we lack the capacity as a community to be fully engaged in tourism or any income generating activities which we feel can benefit us more. We talk about such activities but at the end of the day we say yes to what we are told will get support from either some of these NGOs or the tour operators or government. That's how things are here [Mofolo].

It was further explained by all participants from African Parks that, at Majete, they have had requests from the local communities for them to be engaged in tour guiding but this is failing to materialise as the communities lack the capacity. Though getting involved in tour guiding has been the wish of the local people, by the time of this research, no stakeholder had so far offered to initiate the process of training the local people in tour guiding. As recommended by Wells (1996), Choguill (1996), Novelli and Gebhardt (2007), Spenceley and Goodwin (2007), and Aslam and Bin Awang (2017), there is need for some external support from other stakeholders to build capacity of the local people to ensure their effective participation in tourism.

The reserve's annual business plans have a budget, and only developments or activities that African Parks has finances for-or would be in a position to secure funding for-are included in these plans (African Parks 2013a, 2013b). In this regard, the protected area management agency has an upper hand in influencing local people during tourism planning due to the control that the former has on finances and the better understanding of tourism development issues. As indicated by Botes and Van Rensburg (2000), and Chiutsi and Saarinen (2017), when involving local communities in development-related processes, professionals mostly disempower local people by telling them what to do. In most cases, local communities are not given the opportunity to choose options freely but are given preconceived proposals, and consultations only take place to legitimise the decisions of agencies initiating or sponsoring the process (Hawkins 1993; Garlick 1999; Botes, Rensburg 2000; Rowe, Frewer 2000; Dube 2018). As such, the local communities 
around the reserve are mostly not consulted with the intent of getting their recommendations but just to show that there was some public involvement in the processes.

\section{Transparency}

The local communities indicate that there is no transparency with regard to most management decisions, including issues of tourism development associated with the protected areas. A CBO leader explains as follows:

...African Parks is doing a very good job here but the flow of information to us is at most times erratic. There is some secrecy on how some issues are being handled. We wished some lodges were developed in other parts of the reserve and not just around one area, near African Parks Headquarters for more villages to benefit. You see we first had Thawale Lodge then the campsite now another lodge, Mkulumadzi has also been developed around the same area. Why this is being done, nobody is explaining that to us. This is making our friends around that area benefit more than us [Malizani].

In any community-based tourism planning process, it is essential for the participation process to be transparent to ensure that local communities are aware of what is going on and how decisions are being made (McCool 2009; Grybovych, Hafermann 2010; Nkemngu 2014). Transparency builds good relationships and mutual respect among stakeholders because such local communities need to be consulted and updated frequently on the progress of the tourism planning process (McCool 2009). From the interviews with local people around the reserve, it was noted that the local communities are not aware of the planned number of tourism establishments within the reserve and lack information on how tourism concessions are managed. In most cases, local people just notice things being done, not knowing how and when decisions were made. Seventy-five percent of the local community respondents (12 out of 16) appreciate the role of tourism and favour more tourism developments. The other local community respondents indicated that the management agency had not provided any reason to them on why there are limited tourism establishments within the reserve.
It further emerged that local communities expect that the protected area management agency would be releasing information on most aspects about management of the reserve, including tourism development, park finances and how decisions are made. The lack of transparency is forcing the local people to feel that resources from donors meant for community tourism development or other community projects are being used for other activities. Though the local leadership is aware that the audit reports for African Parks are public documents and available to the public, the audit reports are in English and too technical for most local people to understand (JLC minutes 2012; African Parks 2013a). As noted by Tosun (2000) and Marzuki et al. (2012), inadequate or incomprehensible information and low education levels among the local people can hinder local communities' effective participation in tourism planning processes. It should be noted that not all information pertaining to protected area management, such as law enforcement, can be released to the public. But when there is that need to withhold information for sensitivity, security or other reasons, local communities need to be informed of the nature of the information being withheld and the reasons (Rowe, Frewer 2000).

\section{Resource accessibility}

African Parks commits financial resources for the development of the reserve's business plan (African Parks 2013a). Any planning process needs real commitment from the sponsor by ensuring that appropriate finances are available throughout the process (Rowe, Frewer 2000). As explained by participants from African Parks, their agency organises and finances all JLC meetings and annual stakeholder meetings.

The study has also revealed that local communities around the reserve do not have access to tourism experts during the planning process. It has emerged that African Parks does not have trained tourism planning experts at Majete and mainly relies on conservation education and extension officers when engaging local people in their respective villages during the tourism planning process. These conservation education and extension officers mainly focus on environmental education and very little is done to educate local 
communities on their roles in tourism planning and development associated with the reserve. Some work on building local communities' capacity in tourism is done by a few NGOs, which at times-run programmes to train local people on the available tourism opportunities that can be exploited by the local communities. But the challenge is that there are few NGOs working on wildlife management and tourism, as indicated by a participant from CURE:

... as NGOs we are very minimal working in that area [protected area-based tourism] and we need to improve in terms of awareness, institution should start doing that (...). So, most environmental NGOs will be talking more on agroforestry, food security, but those who are working in the wildife sector are very few [Chidothi].

The limited access to tourism information has made local communities less informed on tourism issues, thereby negatively affecting their effective participation in the tourism planning process. As argued by Jamal and Stronza (2009: 171), "... an informed public is a valuable ally for protected area administrators with respect to gathering support for policy, appreciating the purpose and mandate of the protected area as visitors, and assuming stewardship roles". Murphy (1994), Nkemngu (2014) and Chami (2018) also argue that for a tourist destination to achieve the goal of sustainable development, there is need for cooperation among various groups such as NGOs, industry actors and the government. The lack of NGOs working in the tourism sector in Malawi to provide some civic education on tourism issues resonates with Dieke's (2007) observation that in most sub-Saharan African countries, there are few NGOs working in the tourism sector.

Collaborative outcomes in any planning process depend on mutual understanding and access to information regarding the issues under discussion (Gray 1989). Local communities need to have summaries of pertinent facts about tourism presented to them in the simplest way possible, bearing in mind their literacy levels. Of the local community respondents, $88 \%$ (14 out of 16 ) explained that most of the visual and audio educational material presented to the surrounding communities mainly focuses on environmental conservation. Though the main purpose of the designation of the protected areas is conservation, the management agency acknowledged the need for local communities to benefit from the reserve through tourism. In this regard, tourism development becomes critical in the management agency's efforts to create a supportive constituency for conservation as tourism is one of the economic activities allowed in the reserve to provide benefits to the surrounding local communities.

The other resource that has critically affected local communities' participation in the tourism planning process is time. It was explained by a villager from Majete that:

...most of the people around here are not consistent in attending to protected area management activities due to lack of time. People prioritise attending to their household activities such as farming [Useni].

Most of the local people are preoccupied with subsistence farming and other activities, which they perceive would bring food for their families. Local people need to have enough income to attend to such planning activities without harming their ability to provide for their families (Rowe, Frewer 2000; Tosun 2000; Irvin, Stansbury 2004; Hall 2008). Thus, the inconsistent attendance at tourism planning meetings puts local communities at a disadvantage as they miss out information needed for effective decision-making. As a result, other stakeholders-mostly tour operators, who consistently attend planning activities and are already well informed about the benefits of tourism, and the management agency - have an advantage in terms of influencing the decision-making process to their benefit.

\section{Decision-making structure}

The study revealed that African Parks is responsible for making final decisions on all tourism planning issues. All the stakeholders are aware that the management agency has powers to make final decisions on all issues on tourism development. Other stakeholders are engaged in the planning process, where recommendations pertaining to some aspects of tourism development are made. The Nominal Group Technique is mainly used at Majete during the planning processes in order to enhance stakeholder 
participation. The process assists stakeholders to reach a consensus on various contentious issues when making recommendations.

The participation of local communities in tourism development processes can maximise the socioeconomic benefits of tourism for the communities if the local people are significantly involved in the decision-making processes (Scheyvens 1999; Sène-Harper, Séye 2019). African Parks claims to be focusing on creating opportunities for the local communities to participate in decision-making during the tourism planning process and in the sharing of benefits. In its efforts to develop supportive local communities, African Parks allows the local people-through their CBO representatives - to make decisions on how benefits are shared. It is only in the sharing of tourism benefits that local communities have decision-making powers through the MWRA, but with some oversight being provided by the management agency. It was explained by all the participants from African Parks that the agency provides the oversight to ensure accountability and transparency in the handling of finances mainly from the community campsite, which is the major source of tourism income for the local communities.

During quarterly JLC meetings, African Parks presents progress reports which are subject to discussion. It is in this forum that the local communities make strides in their participation in the decision-making process because most of the unresolved issues between the MWRA and the management agency are discussed at this forum (JLC minutes 2012-2013). One CBO leader explained that the challenge being faced by local community representatives is that JLC meetings are short and issues affecting local people are not given much time during the discussions.

The local communities understand that not all their issues on tourism development can be implemented, but their need is to have an improved flow of information regarding the rationale on which African Parks bases its final decisions regarding tourism development. It was argued by a $\mathrm{CBO}$ representative that

...things would be much better if the bosses of African Parks, not the extension officers can be coming to our local villages to explain some of the issues as they do at JLC meetings. This will assist in clearing some misunderstandings and misconceptions in our villages thinking that African Parks has solutions to all our problems. At times, we as leaders are not believed when we convey some of the decisions [Chiwanda].

The interface between African Parks and local communities at village level is facilitated by $\mathrm{CBO}$ as well as the education and extension officers from African Parks. It is at these village community meetings that all interested villagers have the opportunity to interact with management agency representatives. Unfortunately, these community meetings are mostly attended by junior officers who do not have immediate solutions and answers to issues raised by local people. Most of the outstanding issues are further discussed at the MWRA or JLC meetings held quarterly, and the resolutions are mainly reported back to the communities by CBO representatives. But local community participants recommended that the senior management of African Parks should be directly engaging people at village level.

\section{Conclusion}

This study used the community participation framework for protected area-based tourism (Bello et al. 2016) to assess the tourism planning process at Majete Wildlife Reserve. Using the community participation framework, the paper has highlighted the need for local communities' representation, good timing of involvement and independence of local communities during the planning process. It further looked at the transparency, resource availability and the structure of decision-making during the planning process.

In tourism planning, local communities should be involved as early as possible and preferably from the preparatory stages, through plan development and implementation, up to monitoring and evaluation. As noted in this study, African Parks has a system that allows continuous local community participation in the activities that lead to the development of the reserve's annual business plans.

The protected area management agency at Majete commits financial resources for the tourism planning process. In addition to the financial resources, local communities need to have continued access to informational, human and material resources, to facilitate their effective participation 
in the planning process. This study has revealed that access to financial, human, informational and material resources is a major element in facilitating effective local community participation in tourism planning associated with protected areas. It has been noted in this study that local communities' limited access to tourism information and tourism planning experts is restricting their effective participation in the tourism planning process. Collaborative outcomes in any planning process depend on mutual understanding and access to information regarding the issues under discussion (Gray 1989). Therefore, it is essential for various stakeholders to facilitate access to resources for local communities during the tourism planning process.

African Parks has facilitated the establishment of community organisations in their catchment area to facilitate the interface between the local people and all the other stakeholders during the tourism planning process. In addition to using legitimate local CBOs in the tourism planning process, the local community participants need to fairly represent their respective communities (Bramwell, Sharman 1999). This study shows that local communities value their representation in the tourism planning process through the CBOs. The local community representatives from these $\mathrm{CBOs}$ represent the communities, together with local traditional leaders.

Local community representatives in any tourism planning process are also expected to be independent of any affiliation to any stakeholder involved in the planning process or with interest in any related tourism development (Rowe, Frewer 2000). In this study, local communities elect their own representatives through the CBOs. Further to this, the traditional leaders who participate in the tourism planning process by representing the local people are enthroned through a traditional process, which no other stakeholder can influence. Though there is a need for local community representatives to be independent of other stakeholder groups, the local communities still need external support to develop their capacity to understand tourism issues. This can help ensure their effective participation in the tourism planning process.

As noted by Bahaire and Elliot-White (1999), and Chiutsi and Saarinen (2017), the issue of power relations and external influence has mainly been underemphasised in local community participation in tourism. Empirical evidence from this study shows that local communities need to be regarded as partners in the tourism planning process. This ensures that they are not influenced to behave or act or take positions on an issue that is not in their own immediate interest. In any tourism planning process, local communities need to be empowered for them to have influence and control over issues and initiatives that have an impact on their livelihood. Local community empowerment during the planning process is mainly achieved by ensuring that local people have access to resources. As noted in this study, local communities would like to have their capacities in tourism developed so that they can effectively influence the decision-making process rather than just rubber-stamping preconceived proposals.

In any tourism planning process, transparency among stakeholders on issues about tourism development reduces any possible suspicions about the motives of the planning authority or other stakeholders. Deliberations among stakeholders during the planning process should be conducted in an open manner. Local communities need to be aware of what is going on and how decisions are being made during the tourism planning process. As noted in this study, local communities prefer to have a well-structured decision-making process that would facilitate better flow of information about any tourism planning and development decisions that may have a direct impact on their livelihood.

Local community participants argued that the protected area management agency's transparency, together with a proper flow of tourism information, can facilitate their effective participation in the tourism planning process. Local communities in and around protected areas need to be updated with information on most of the aspects of protected area management, including tourism development, protected area finances and reasons underlying some management decisions. As noted by Tosun (2000) and Marzuki et al. (2012), inadequate or incomprehensible tourism information can hinder effective local community participation in the tourism planning process.

The use of appropriate mechanisms in structuring the decision-making process is another 
major participatory planning element that facilitates the effective participation of local communities in tourism planning. This element is directly related to transparency as it involves setting up a planning system that is transparent and supports the flow of information to all stakeholders during the planning process. It has been noted in this study that although the responsibility to make final tourism planning decisions is the responsibility of the protected area management agency, the local communities' major concern has only been the lack of a system that allows them to get information regarding the underlying reasons for the decisions that have been made. Although the local communities would be happy to be directly involved in the decision-making process, a transparent decision-making structure can facilitate effective participation of local communities in tourism planning associated with the reserve.

\section{References}

African Parks, 2013a. African Parks: Annual Report 2012. Online: https://www.african-parks.org/sites/default/ files/uploads/resources/2017-05/APN_AnnualReport_2012.pdf (accessed: 15 September 2019).

African Parks, 2013b. Majete tourism development plan 20132016. Majete Wildlife Reserve, Chikwawa.

Arskey H., Knight P., 1999. Interviewing in social scientist: An introductory resource with examples. Sage, London.

Ashley C., Roe D., 1998. Enhancing community involvement in wildlife tourism: Issues and challenges. Wildlife and Development Series No. 11. IIED, London.

Ashley K.S., Osmani M., Emmitt S., Mallinson M., Mallinson H., 2015. Assessing stakeholders' perspectives towards the conservation of the built heritage of Suakin, Sudan. International Journal of Heritage Studies 21(7): 674-697. DOI 10.1080/13527258.2014.985696.

Aslam M.S.M., Bin Awang K.W., 2017. Implications of policies and procedures in Sustainable Rural Tourism Development (SRTD): A case study of Sri Lanka. Sabaragamuwa University Journal 15(1): 74-93. DOI 10.4038/suslj. v15i1.7708.

Bahaire T., Elliott-White M., 1999. Community participation in tourism planning and development in the historic city of York, England. Current Issues in Tourism 2(2-3): 243276. DOI 10.1080/13683509908667854.

Baidal J.A.I., 2004. Tourism planning in Spain - Evolution and perspectives. Annals of Tourism Research 31(2): 313 333. DOI 10.1016/j.annals.2003.12.001.

Bello F.G., Carr N., Lovelock B., 2016. Community participation framework for protected area based tourism planning. Tourism Planning and Development 13(4): 469-485. DOI 10.1080/21568316.2015.1136838.

Bello F.G., Lovelock B., Carr N., 2017. Constraints of community participation in protected area-based tourism planning: The case of Malawi. Journal of Ecotourism 16(2): 131-151. DOI 10.1080/14724049.2016.1251444.
Botes L., Van Rensburg D., 2000. Community participation in development: Nine plagues and twelve commandments. Community Development Journal 35(1): 41-58. DOI 10.1093/cdj/35.1.41.

Bramwell B., Higham J., Lane B., Miller G., 2017. Twenty five years of sustainable tourism: Looking back and moving forward. Journal of Sustainable Tourism 25(1): 1-9. DOI 10.1080/09669582.2017.1251689.

Bramwell B., Sharman A., 1999. Collaboration in local tourism policymaking. Annals of Tourism Research 26(2): 392415. DOI 10.1016/S0160-7383(98)00105-4.

Bryman A., Bell E., 2007. Business research methods. Oxford University Press, Oxford.

Chami M.F., 2018. Community involvement and sustainable tourism development in heritage management: Amboni Limestone caves, Tanzania. African Journal of Hospitality, Tourism and Leisure 7(2): 1-13.

Chisnall P., 2005. Marketing research. McGraw Hill Education, Berkshire.

Chiutsi S., Saarinen J., 2017. Local participation in transfrontier tourism: Case of Sengwe Community in Great Limpopo Transfrontier Conservation Area, Zimbabwe. Development Southern Africa 34(3): 260-275. DOI 10.1080/0376835X.2016.1259987.

Chiutsi S., Saarinen J., 2019. The limits of inclusivity and sustainability in transfrontier peace parks: Case of Sengwe Community in Great Limpopo Transfrontier Conservation Area, Zimbabwe. Critical African Studies 11(3): 348360. DOI 10.1080/21681392.2019.1670703.

Choguill M.B.G., 1996. A ladder of community participation for underdeveloped countries. Habitat International 20(3): 431-444. DOI 10.1016/0197-3975(96)00020-3.

Clarke J.E., 1983a. Protected areas master plan for southern region. Department of National Parks and Wildlife, Lilongwe.

Clarke J.E., 1983b. Principal master plan for national parks and wildlife management. Department of National Parks and Wildlife, Lilongwe.

Creswell J.W., 2009. Research design: Qualitative, quantitative, and mixed methods Approaches. Sage, Thousand Oaks; London.

de Kadt E., 1979. Social planning for tourism in the developing countries. Annals of Tourism Research 6(1): 36-48. DOI 10.1016/0160-7383(79)90093-8.

Department of Tourism, 2006. National tourism policy. Department of Tourism, Lilongwe.

Dieke P.U.C., 2007. Participatory approaches to tourism development: An example from sub-Saharan Africa. In: Kloek M.E., van der Duim R. (eds), Local communities and participation in African tourism: Thematic proceedings of ATLAS Africa Conferences Volume 2. ATLAS, The Netherlands.

DNPW, 2000. Majete Wildlife Reserve: Park plan. Department of National Parks and Wildlife, Lilongwe.

Dodds R., Ali A., Galaski K., 2018. Mobilizing knowledge: Determining key elements for success and pitfalls in developing community-based tourism. Current Issues in Tourism 21(13): 1-22. DOI 10.1080/13683500.2016.1150257.

Dragouni M., Fouseki K., 2018. Drivers of community participation in heritage tourism planning: An empirical investigation. Journal of Heritage Tourism 13(3): 237-256. DOI 10.1080/1743873X.2017.1310214.

Dube C.N., 2018. Community participation in the management of South Africa's protected areas. African Journal of Hospitality, Tourism and Leisure 7(2): 1-18. 
Dudley N., Stolton S., 2018. Protected Areas: Challenges and responses for the coming decade. Equilibrium Research, Bristol.

Eagles P.F.J., McCool S.F., Haynes C.D., 2002. Sustainable tourism in protected areas: Guidelines for planning and management, Vol. No. 8. IUCN, Gland, Switzerland. DOI 10.1079/9780851995892.0000.

Garlick S., 1999. The Australian history of government intervention in regional development. In: Dore J., Woodhill J. (eds), Sustainable rural development: Final report. Greening Australia, Canberra, Australia: 177-186.

Giampiccoli A., Glassom D., 2021. Community-based tourism in protected areas: Elaborating a model from a South African perspective. Advances in Hospitality and Tourism Research (AHTR) 9(1): 106-131. DOI 10.30519/ ahtr.741805.

Gray B., 1989. Collaborating: Finding common ground for multiparty problems. Jossey-Bass Publishers, San Francisco, California.

Grybovych O., Hafermann D., 2010. Sustainable practices of community tourism planning: Lessons from a remote community. Community Development 41(3): 354-369. DOI $10.1080 / 15575330903444085$.

Gunn C.A., Var T., 2002. Tourism planning: Basics, concepts and cases. Routledge, New York.

Hall C.M., 2008. Tourism planning: Policies, processes and relationships. Pearson Education, Harlow.

Hawkins D., 1993. Global assessment of tourism policy. In: Pearce D., Butler R. (eds), Tourism research: Critiques and challenges. Routledge, London: 175-200.

Hayes G., 1972. Wildlife conservation in Malawi. The Society of Malawi Journal 25(2): 22-31.

Haywood K.M., 1988. Responsible and responsive tourism planning in the community. Tourism management 9(2): 105-118. DOI 10.1016/0261-5177(88)90020-9.

Inskeep E., 1994. National and regional tourism planning: Methodologies and case studies. Routledge, London.

Irvin R.A., Stansbury J., 2004. Citizen participation in decision making: Is it worth the effort? Public Administration Review 64(1): 55-65. DOI 10.1111/j.1540-6210.2004.00346.x.

Jamal T., Stronza A., 2009. Collaboration theory and tourism practice in protected areas: Stakeholders, structuring and sustainability. Journal of Sustainable Tourism 17(2): 169189. DOI $10.1080 / 09669580802495741$.

Lalicic L., Onder I., 2018. Residents' involvement in urban tourism planning: Opportunities from a smart city perspective. Sustainability 10(6): 1852. DOI 10.3390/ su10061852.

Lalicic L., Weber-Sabil J., 2020. Stakeholder engagement in sustainable tourism planning through serious gaming. Tourism Geographies 23(1-2): 185-205. DOI 10.1080/14616688.2019.1648543.

Lekaota L., 2016. Rural communities' participation in the planning and management of tourism developments: A case study of Lesotho. African Journal of Hospitality, Tourism and Leisure 5(4): 1-12. DOI 10.1108/ WHATT-06-2015-0029.

Mahony K., Van Zyl J., 2002. The impacts of tourism investment on rural communities: Three case studies in South Africa. Development Southern Africa 19(1): 83-103. DOI 10.1080/03768350220123891.

Malawi Government, 2001. Growing Tourism in Malawi's Protected Areas: Tourism Concessions Guidelines and Procedures. DNPW, Lilongwe.

Malawi Government, 2005. Liwonde - Mangochi Protected Area Complex General Management Plan 2005-2015. DNPW, Lilongwe.
Mandić A., 2020. Structuring challenges of sustainable tourism development in protected natural areas with driving force-pressure-state-impact-response (DPSIR) frameworks. Environment Systems and Decisions 40: 560-576. DOI 10.1007/s10669-020-09759-y.

Marzuki A., Hay I., James J., 2012. Public participation shortcomings in tourism planning: The case of the Langkawi Islands, Malaysia. Journal of Sustainable Tourism 20(4): 585-602. DOI 10.1080/09669582.2011.638384.

Mbaiwa J.E., 2005a. The socio-cultural impacts of tourism development in the Okavango Delta, Botswana. Journal of Tourism and Cultural Change 2(3): 163-185. DOI 10.1080/14766820508668662.

Mbaiwa J.E., 2005b. Wildlife resource utilisation at Moremi Game Reserve and Khwai community area in the Okavango Delta, Botswana. Journal of Environmental Management 77(2): 144-156. DOI 10.1016/j.jenvman.2005.03.007.

Mbaiwa J.E., 2005c. Enclave tourism and its socio-economic impacts in the Okavango Delta, Botswana. Tourism Management 26(2): 157-172. DOI 10.1016/j.tourman.2003.11.005.

Mbaiwa J., 2003. The socio-economic and environmental impacts of tourism development on the Okavango Delta, north-western Botswana. Journal of Arid Environments 54(2): 447-467. DOI 10.1006/jare.2002.1101.

McCool S.F., 2009. Constructing partnerships for protected area tourism planning in an era of change and messiness. Journal of Sustainable Tourism 17(2): 133-148. DOI $10.1080 / 09669580802495733$.

Moswete N., Thapa B., 2018. Local communities, CBOs/ trusts, and people-park relationships: A case study of the Kgalagadi Transfrontier Park, Botswana. The George Wright Forum 35(1): 96-108.

Mowforth M., Munt I., 2009. Tourism and sustainability: Development, globalisation and new tourism in the third world. Routledge, London. DOI 10.4324/9780203891056.

Murphy P.E., 1994. Tourism and sustainable development. In: Theobald W.F. (ed.), Global tourism: The next decade. Butterworth-Heinemann, Oxford. 274-90

Murphy P., 1985. Tourism: A community approach. Methuen, New York.

Nkemngu A.P., 2014. Stakeholder's participation in township tourism planning and development: The case of business managers in Shoshanguve. African Journal of Hospitality, Tourism and Leisure 3(1): 1-10.

Novelli M., Barnes J.I., Humavindu M., 2006. The other side of the ecotourism coin: Consumptive tourism in Southern Africa. Journal of Ecotourism 5(1-2): 62-79. DOI $10.1080 / 14724040608668447$.

Novelli M., Gebhardt K., 2007. Community based tourism in Namibia: 'Reality show' or 'window dressing'? Current Issues in Tourism 10(5): 443-479. DOI 10.2167/cit332.0.

Novelli M., Scarth A., 2007. Tourism in protected areas: Integrating conservation and community development in Liwonde National Park (Malawi). Tourism and Hospitality Planning \& Development 4(1): 47-73. DOI 10.1080/14790530701289697.

Nowacki M., Kowalczyk-Aniol J., Krolikowska K., Pstrocka-Rak M., Awedyk M., (2018). Strategic planning for sustainable tourism development in Poland. International Journal of Sustainable Development \& World Ecology 25(6): 562-567. DOI 10.1080/13504509.2018.1432513.

NSO, 2020. The Fifth Integrated Household Survey (IHS5) 2020 Report. National Statistical Office of Malawi, Zomba, Malawi. 
Nunkoo R., Gursoy D., 2016. Rethinking the role of power and trust in tourism planning. Journal of Hospitality Marketing \& Management 25(4): 512-522. DOI 10.1080/19368623.2015.1019170.

Okazaki E., 2008. A community-based tourism model: Its conception and use. Journal of Sustainable Tourism 16(5): 511-529. DOI 10.1080/09669580802159594.

Panichm P., Hasachoo N., Sirisawat P., 2018. Key success factors for improving community-based tourism supply chain. UTCC Academic Day. 8 June, University of Thai Chamber of Commerce.

Patton M.Q., 2002. Qualitative research \& evaluation methods. Sage, Thousand Oaks, CA.

Paul S., 1987. Community participation in development projects. World Bank, Washington, DC.

Pearce D.G., 1991. Tourism development. John Wiley \& Sons, New York.

Pyke J., Law A., Jiang M., de Lacy T., 2018. Learning from the locals: The role of stakeholder engagement in building tourism and community resilience. Journal of Ecotourism 17(3): 206-219. DOI 10.1080/14724049.2018.1505586.

Rasoolimanesh S.M., Jaafar M., Ahmad A.G., Barghi R., 2017. Community participation in World Heritage Site conservation and tourism development. Tourism Management 58: 142-153. DOI 10.1016/j.tourman.2016.10.016.

Rowe G., Frewer L.J., 2000. Public participation methods: A framework for evaluation. Science, Technology, \& Human Values 25(1): 3-29. DOI 10.1177/016224390002500101.

Saufi A., O'Brien D., Wilkins H., 2014. Inhibitors to host community participation in sustainable tourism development in developing countries. Journal of Sustainable Tourism 22(5): 801-820. DOI 10.1080/09669582.2013.861468.

Scheyvens R., 1999. Ecotourism and the empowerment of local communities. Tourism Management 20(2): 245-249. DOI 10.1016/S0261-5177(98)00069-7.

Sène-Harper A., Séye M., 2019. Community-based tourism around national parks in Senegal: The implications of colonial legacies in current management policies. Tourism Planning \& Development 16(2): 217-234. DOI 10.1080/21568316.2018.1563804.

Simmons D.G., 1994. Community participation in tourism planning. Tourism Management 15(2): 98-108. DOI 10.1016/0261-5177(94)90003-5.
Snyman S.L., 2012. The role of tourism employment in poverty reduction and community perceptions of conservation and tourism in southern Africa. Journal of Sustainable Tourism 20(3): 395-416. DOI 10.1080/09669582.2012.657202.

Spenceley A., Goodwin H., 2007. Nature-based tourism and poverty alleviation: Impacts of private sector and parastatal enterprises in and around Kruger National Park, South Africa. Current Issues in Tourism 10(2-3): 255-277. DOI 10.2167/ cit305.0.

Stone L.S., Stone T.M., 2011. Community-based tourism enterprises: Challenges and prospects for community participation; Khama Rhino Sanctuary Trust, Botswana. Journal of Sustainable Tourism 19(1): 97-114. DOI 10.1080/09669582.2010.508527.

Stone M.T., Nyaupane G.P., 2018. Protected areas, wildlife-based community tourism and community livelihoods dynamics: Spiraling up and down of community capitals. Journal of Sustainable Tourism 26(2): 307-324. DOI 10.1080/09669582.2017.1349774.

Strydom A.J., Mangope D., Henama U.S., 2018. Lessons learned from successful community-based tourism case studies from the Global South. African Journal of Hospitality, Tourism and Leisure 7(2): 1-13.

Tosun C., 1999. Towards a typology of community participation in the tourism development process. Anatolia 10(2): 113-134. DOI 10.1080/13032917.1999.9686975.

Tosun C., 2000. Limits to community participation in the tourism development process in developing countries. Tourism Management 21(6): 613-633. DOI 10.1016/S02615177(00)00009-1.

Tosun C., Jenkins C.L., 1998. The evolution of tourism planning in Third-World countries: A critique. Progress in Tourism and Hospitality Research 4(2): 101-114. DOI 10.1002/ (SICI)1099-1603(199806)4:2<101::AID-PTH100>3.0.CO;2-Z.

Wells M.P., 1996. The social role of protected areas in the new South Africa. Environmental Conservation 23(04): 322-331. DOI 10.1017/S0376892900039187.

Zhang Y., Xiao X., Cao R., Zheng C., Guo Y., Gong W., Wei Z., 2020. How important is community participation to eco-environmental conservation in protected areas? From the perspective of predicting locals' pro-environmental behaviours. Science of the Total Environment 739; 2020. DOI 10.1016/j.scitotenv.2020.139889. 